\title{
Dot enzyme-linked immunosorbent assay (dot-ELISA) for schistosomiasis diagnosis using dacron as solid-phase
}

\author{
Dot-ELISA (dot enzyme-linked immunosorbent assay), utilizando o dacron \\ como suporte sólido para o diagnóstico da esquistossomose
}

\author{
Silvia Maria Lucena Montenegro, Joanne D'arc Bezerra da Silva, \\ Maria Edileuza Felinto de Brito and Luiz Bezerra de Carvalho Junior
}

\begin{abstract}
Dacron and nitrocellulose were evaluated as matrices for the dot enzyme linked immunosorbent assay (dot-ELISA) for schistosomiasis and compared to indirect immunofluorescence (IMF). Titration of sera from 18 schistosomiasis patients against soluble worm antigen preparation (SWAP) was carried out and sera from healthy individuals from nonendemic areas were used as controls. The IMF was less sensitive than the dot-ELISAs, although the difference was not statistically significant $(p>0.05)$. The dot-ELISA based on nitrocellulose was as sensitive as that using dacron. Stability did not differ between nitrocellulose and dacron. Specificity was lower when dacron was used than when nitrocellulose was used, although the difference was not statistically significant $(p>0.05)$. In conclusion, this work showed that nitrocellulose and dacron performed similarly in dot-ELISA, suggesting that they may be used alternatively in population surveillance in endemic areas.
\end{abstract}

Key-words: dot-ELISA. Dacron. Schistosoma mansoni.

Resumo $O$ dacron e a nitrocelulose foram utilizados como matrizes para realização do dotELISA na esquistossomose e comparadas com a imunofluorescência indireta (IMF). A titulação dos soros de 18 pacientes esquistossomóticos foi feita, utilizando o antígeno solúvel de verme adulto (SWAP) e soro de pessoas normais não endêmicas foram usadas como controle. A IMF foi menos sensível do que os dot-ELISAs, apesar da diferença não ter sido estatisticamente significativa $(p>0,05)$. O dot-ELISA, utilizando a nitrocelulose foi tão sensível do que aquele utilizando o dacron como suporte. Não houve diferenças significativas entre os suportes em relação à estabilidade do antígeno. Entretanto, a especificidade, utilizando o dacron como suporte foi menor do que a nitrocelulose, apesar da diferença não ter sido estatisticamente significativa $(p>0,05)$. Em resumo, este trabalho mostrou que os resultados dos suportes utilizados em dot-ELISA para o diagnóstico da esquistossomose mansônica foram semelhantes, sugerindo que, o dacron também pode ser usado em levantamentos populacionais de areas endêmicas.

Palavras-chaves: dot-ELISA. Dacron. Schistosoma mansoni.

\footnotetext{
Departamento de Imunologia, Laboratório de Bioquímica e Biologia Molecular do Centro de Pesquisas Aggeu Magalhães - Fundação Oswaldo Cruz e Departamento de Bioquímica e Laboratório de Imunopatologia Keizo Asami (LIKA), Universidade Federal de Pernambuco, Recife, PE.

This work was supported by CNPq, FACEPE, FIOCRUZ and JICA.

Address to: Dra. Silvia M.L. Montenegro. Centro de Pesquisas Aggeu Magalhães/FIOCRUZ. Av. Moraes Rego s/n, 50670-420 Recife, PE, Brasil.

Fax: 55081 453-1911.

Recebido para publicação em 27/2/98.
} 
Immunodiagnostic techniques for schistosomiasis have been available since early this century 720 and have increased considerably in the last years due to a better understanding of the host-parasite interaction and the introduction of new concepts and methodologies 15 .

The search for more sensitive, specific, practical and less expensive diagnostic tests has led to the development of a great number of immunological tests that could complement the limitations of the parasitological diagnosis 15 . Dot enzyme-linked immunosorbent assay (dot-ELISA) has been widely employed in several serologic tests because it does not need either sophisticated equipment or specialized personnel. Nitrocellulose is the most used matrix 1011 due to the facility to handle it and the quality of the color developed 20 , although it is very expensive. In 1987, Boctor et al3, proposed the use of nitrocellulose strips as a matrix in dot-ELISAfor human schistosomiasis mansoni.

In our laboratory, dacron (polyethyleneterephthalate) has been used as solid phase in dot-ELISA for plague diagnosis 14 17. This polyester has also been previously employed to immobilize enzymes yielding active derivatives 5681822 .

In this work, soluble worm antigen preparation (SWAP) was covalently linked to dacron and dotELISA was tested for diagnosis of schistosomiasis. Comparative studies were carried out with dotELISA on nitrocellulose filters and indirect immunofluorescence assay (IMF).

\section{MATERIALAND METHODS}

Antigen. SWAP (soluble worm antigen preparation) from Schistosoma mansoni was obtained according to Boctor and Shaheen². Sera from 18 patients presenting chronic schistosomiasis were obtained from Hospital das Clínicas, UFPE. Sera from 8 individuals from non-endemic areas and phosphate buffer saline (PBS) were used as negative controls. Sera from patients with Chagas' disease (3 patients), malaria (4 patients) and filariasis (3 patients) were used to test cross reactivity. Anti-human IgG labeled with horseradish peroxidase and 3,3-diaminobenzidine tetrahydrochloride (DAB) were purchased from Sigma, Chem. Co., St. Louis, MO. Tween 20 was acquired from Inlab. Dacron was produced by Rhodia do Brazil S.A. Nitrocellulose filter $(0.22 \mu \mathrm{m}$ pore size) was from Millipore, Inc., Bedford, MA. All other reagents of analytical grade were obtained from Merck S.A., Brazil.

Dacron. Dacron plates were activated according to Oliveira et al 17 as modified by Montenegro et al13.

Dot-ELISA. This technique was performed according to Pappas et al18. One ul of SWAP antigen $(0.25 \mu \mathrm{g} / \mu \mathrm{l})$ was spotted onto the azidadacron plates and nitrocellulose filters and kept at $37^{\circ} \mathrm{C}$ for $30 \mathrm{~min}$ to dry. The antigen-dacron plates and antigen-nitrocellulose preparations were introduced into the wells of a Nunc multidish plate and stored at $4^{\circ} \mathrm{C}$ overnight. Protein concentration was evaluated according to Bradford et al (1976)4. The blocking substance used was $30 \%(\mathrm{w} / \mathrm{v})$ non-fat instant milk (Fleichmann and Royal Ltda., Brazil) solution
$(0.4 \mathrm{ml})$ prepared in PBS, $\mathrm{pH} 7.2$, containing $0.05 \%(\mathrm{v} / \mathrm{v})$ Tween-20 (PBS-Tween 20) and kept for $15 \mathrm{~min}$ with gentle stirring. The blocking solution was aspirated out and the plates were washed three times with PBS-Tween 20 with shaking, during $1 \mathrm{~min}$ each and the last wash was preceeded by a 10 min incubation without stirring. The serum samples and controls were serially diluted in PBS-Tween 20 from 1:16 to $1: 65,536$ and introduced into the wells containing the blocked antigen-dacron plates or antigennitrocellulose filters. The plates and filters were shaken for $1 \mathrm{~min}$ at $25^{\circ} \mathrm{C}$, incubated for $30 \mathrm{~min}$ and the washing procedure was carried out as described for the blocking. Anti-rabbit IgG peroxidase conjugate (IgG-HRP) was diluted $1: 1,000$ in PBS and $0.6 \mathrm{ml}$ was pipetted into each well. The plate was shaken for $1 \mathrm{~min}$ and incubated for $30 \mathrm{~min}$. The plates and filters were washed five times as described before. The development of the spot was perfomed according to Montenegro et al (1991)14.

Indirect Immunofluorescence assay (IMF). This technique was undertaken according to Helden et al (1975) 9 and cercariae obtained from infected Biomphalaria glabrata were used as antigen.

Temporal and thermal stabilities of the antigen. Antigen-dacron plates and antigennitrocellulose filters were stored at $28^{\circ} \mathrm{C}, 4^{\circ} \mathrm{C}$ and $-20^{\circ} \mathrm{C}$ for a time ranging from 7 to 90 days. Then, dot-ELISA was carried out according to the methodology described using positive sera in PBS-Tween and anti IgG-HRP conjugate in PBS at dilutions of $1: 100$ and 1:1,000, respectively. 
Statistical analysis. A 95\% confidence quisquare test $\left(\chi^{2}\right)$ was used for comparison between the sensitivities and especificities of different assays.

\section{RESULTS}

The titration of sera obtained from schistosomiasis patients by using IMF and dotELISA on nitrocellulose and dacron is shown in Table 1. Two patients (numbers 6 and 18) were negative by using IMF tests and positive by using dot-ELISAs. In the control group (non-endemic area), only one individual showed a spot at a dilution of 1:64 when nitrocellulose was used as matrix. When dacron was used as matrix, spots were shown at dilutions of 1:32 (three persons) and 1:256 (one person). No positive reaction was observed using PBS as negative control. Based upon these results we established a cutoff point of 1:256 for both matrices. All sera from
S. mansoni patients reacted positively in both nitrocellulose and dacron, resulting in a sensitivity of $100 \%$.

All malaria sera $(n=4)$ and one out of 3 filariasis sera were reactive at 1:512 dilution and were considered cross-reactions using dacron as solid phase while no sera from Chagas' disease patients $(n=3)$ were reactive. Using nitrocelulose as solid phase no cross-reactivity was observed. The specificity for nitrocellulose and dacron was $100 \%$ and $87.5 \%$, respectively, although the difference was not statistically significant $(p>0.05)$.

Table 1 - Titration of sera from schistosomiasis patients by using indirect immunofluorescence assay and dot-ELISAs on dacron and nitrocellulose (reciprocal titers).

\begin{tabular}{|c|c|c|c|}
\hline \multirow[b]{2}{*}{ Patients } & \multirow[b]{2}{*}{ IMF } & \multicolumn{2}{|c|}{ Dot-ELISA } \\
\hline & & Dacron & Nitrocellulose \\
\hline 1 & 256 & 4,096 & 8,196 \\
\hline 2 & 256 & 1,024 & 4,096 \\
\hline 3 & 256 & 2,048 & 4,096 \\
\hline 4 & 128 & 4,096 & 2,048 \\
\hline 5 & 512 & 8,192 & 16,384 \\
\hline 6 & neg & 1,024 & 4,096 \\
\hline 7 & 128 & 4,096 & 2,048 \\
\hline 8 & 128 & 4,096 & 4,096 \\
\hline 9 & 128 & 512 & 1,024 \\
\hline 10 & 128 & 2,048 & 8,192 \\
\hline 11 & 128 & 1,024 & 1,024 \\
\hline 12 & 128 & 1,024 & 2,048 \\
\hline 13 & 256 & 4,096 & 8,192 \\
\hline 14 & 256 & 512 & 1,024 \\
\hline 15 & 256 & 2,048 & 8,192 \\
\hline 16 & 128 & 2,048 & 2,048 \\
\hline 17 & 128 & 512 & 1,024 \\
\hline 18 & neg & 8,192 & 8,192 \\
\hline
\end{tabular}

neg = negative

The IMF using as cut-off point a 1:64 dilution was less sensitive (88.9\%) than the dot-ELISAs, although the difference was not statistically significant $(p>0.05)$.

Dot-ELISA carried out on antigen-dacron plates stored at $-20^{\circ} \mathrm{C}$ at 60 days still showed the same spot intensity as those recently prepared. The antigen-dacron plates stored at $4^{\circ} \mathrm{C}$ presented weaker reactions at 15, 30 and 60 days and stored at $28^{\circ} \mathrm{C}$ for 60 days it was not suitable for diagnosis. The results on stability were not so different regarding nitrocellulose dot-ELISA (Table 2). 
Table 2 - Determination of antigen stability on dacron and nitrocellulose in relation to time and temperature.

\begin{tabular}{|c|c|c|c|c|c|c|}
\hline \multirow[t]{2}{*}{ Days } & \multicolumn{3}{|c|}{ Nitrocellulose } & \multicolumn{3}{|c|}{ Dacron } \\
\hline & $4^{\circ} \mathrm{C}$ & $28^{\circ} \mathrm{C}$ & $-20^{\circ} \mathrm{C}$ & $4^{\circ} \mathrm{C}$ & $28^{\circ} \mathrm{C}$ & $-20^{\circ} \mathrm{C}$ \\
\hline 7 & ++ & ++ & ++ & ++ & ++ & ++ \\
\hline 15 & ++ & ++ & ++ & + & + & ++ \\
\hline 30 & + & + & + & + & $+/-$ & ++ \\
\hline 60 & + & + & + & + & - & ++ \\
\hline
\end{tabular}

\section{DISCUSSION}

We have previously studied the dacron as a solid matrix in a dot-ELISA with plague bacillus antigen and found results as good as the nitrocellulose that is the most common matrix used 114 . Nitrocellulose is the most widely used matrix but it is very expensive and the dacron has the advantage that can be obtained at very low cost. In this study, we evaluated the perfomance of dacron and a dot-ELISAto detect antibodies to schistosome worm antigen.

The only false positive reaction using sera from non-endemic control group and the crossreactions with malaria and one filaria sera was in dacron matrix. In the first case this could be attributed to the fact that these individuals may have been parasited by several others helminth species and could have cross-reactions in the dot-ELISA3. We have no explanation for the positive reaction of sera from malaria patients; we do not know whether they had ever been in an endemic area for schistosomiasis. On the other hand, it is well known that, cross reaction between Schistosoma and filaria antigens can be observed regularly in ELISA 14 .

The present results demonstrate that nitrocellulose and dacron perform similarly in dot-ELISA. Thus, taking into account that dacron can be obtained at very low cost, it is easily available, presents the same sensitivity of nitrocellulose (although our study is preliminary) and covalently linked antigens are stable for long periods, we suggest that this material could be used as an alternative matrix in surveillance of populations in endemic areas. According to Mott and Dixon (1982) ${ }^{16}$, one point that has been generally accepted in immunological tests is that improvement in the specificity of immunodiagnostic test will depend on the availability of pure antigens. We are currently assaying the dacron matrix with purified antigens and increasing the size of the sample studied.

\section{ACKNOWLEDGEMENTS}

We are grateful to Dr. Frederico G.C. Abath for his critical reading of the manuscript and, $\mathrm{Mr}$
O.T. da Costa and Miss V.S.F. Leão for their technical assistance.

\section{REFERENCES}

1. Almeida AMP, Ferreira LCS. Evaluation of three serological tests for the detectionof human plague in northeast Brazil. Memórias do Instituto Oswaldo Cruz 87:87-92, 1992.

2. Boctor FN, Shaheen, HI. Immunoaffinity fractionation of Schistosoma mansoni worm antigens using human antibodies and its application for serodiagnosis. Immunology 57:587-593, 1986.

3. Boctor FN, Steck MJ, Peter JB, Kamal R. Simplification and standardization of dot-ELISA for human schistosomiasis mansoni. Journal of Parasitology 73:589-592, 1987.

4. Bradford MM. A rapid and sensitive method for the quantitation of microgram quantities of protein utilizing the principle of protein dye binding. Analytical Biochemistry 72:248-254, 1976.
5. Carvalho Jr LB, Melo EHM, Vasconcelos ARA, Lira RR. Glucose oxidase immobilised on gel beads polyacrylamide and polyethyleneterephthalate. Arquivos de Biologia e Tecnologia 29:525-531, 1986.

6. Carvalho Jr LB, Silva MPC, Melo EHM. Activity of immobilized $\alpha$-amylase. Brazilian Journal of Medical and Biological Research 201:521-526, 1987.

7. Fujinami A, Nakamura $H$. Experimental studies on the serological reactions in calves experimentally infected with Schistosoma japonicum. Journal of Kyoto Medical Association 6:224-252, 1909.

8. Goldstein L, Freeman A, Blassberger D, Granot R, Sorolovsky M. Chemically modified polymers containing isocyanide functional groups as support for enzyme immobilization. In: Bohak Z, Sharon N (eds) Biotechnological Applications of Proteins and Enzymes. Academic Press, New York, p. 153-167, 1977. 
9. Helden HPT, Van Terpsttra WJ, Okot-Kotber BM, Eyakuze VM. Are these characteristic immunofluorescence patterns in schistosomiasis? Transactions of The Royal Society of Tropical Medicine and Hygiene 69:309-311, 1975.

10. Herbrink P, Van Bussel FJ, Warnaar SO. The antigen spot test (AST): a highly sensitive assay for the detection of antibodies. Journal of Immunology Methods 48:293298, 1982.

11. Huet J, Sentenac A, Fromageot P. Spot-immunodetection of conserved determinants in eukaryotic RNA polymerases. Journal of Biological Chemistry 257:2613-2618, 1982.

12. Janitschke K, Reinhold A, Bode, L. Nitrocellulose dotELISA for serodiagnosis of schistosomiasis. Transactions of the Royal Society of Tropical Medicine and Hygiene 81: 956-958, 1987.

13. Montenegro SML. Immunodiagnosis. Memórias do Instituto Oswaldo Cruz 87:333-335, 1992.

14. Montenegro SML, Almeida AMP, Carvalho AB, Carvalho Jr LB. The use of dacron plates for dot enzyme linked immunosorbent assay (dot-ELISA). Memórias do Instituto Oswaldo Cruz 86: 461-465, 1991.

15. Montenegro SLM, Almeida AMP, Carvalho Jr LB. Standardization of the dot enzyme-linked immunosorbent assay (Dot-ELISA) for experimental plague. Memórias do Instituto Oswaldo Cruz 88:119-123, 1993.

16. Mott KE, Dixon H. Collaborative study for immunodiagnosis of schistosomiasis. Bulletin of the World Health Organization 60:729-753, 1982.

17. Oliveira EA, Silva MPC, Figueiredo ZMB, Carvalho Jr LB. Immobilization of proteins on plate of dacron. Applied Biochemistry and Biotechnology 22:109-114, 1989.

18. Pappas MG, Hajkowski R, Hockmeyer WT. Standardization of the dot enzyme-linked immunosorbent assay (dotELISA) for human visceral Leishmaniasis. American Journal of Tropical and Medicine Hygiene 33:1105-1111, 1984.

19. Renner SW. Immunoblotting and dot immunobinding. Archives of Pathology and Laboratory Medicine 112:780:786, 1988.

20. Taliaferro WH, Hoffman WA, Cook DH. A precipitin test in intestinal schistosomiasis, S. mansoni. Journal of Preventive Medicine 2:395, 1928.

21. Weetall HH. Insolubilized L-aspariginase implant: a preliminary report. Journal of Biomedical Materials Research 4:597-599, 1970. 